\title{
The Inequality of the Provinces in China: A Productivity Analysis
}

\author{
S. G. Chan
}

\begin{abstract}
This paper intends to address the issue of the inequality in the economy development in China with the use of Total Factor Productivity in analyzing the productivity and efficient used of resources. The study focuses on regional analysis to determine the inequality patterns among the provinces in China with the objective to address the issues of inequality among the provinces in China which my dampened the economic development in the country. The sample of the study consist of 30 provinces in China starts from year 1978 to 2008 in order to investigate the economic efficiency and productivity change of the Chinese's economy after the China reformation in 1978. The results show that the Eastern region is relatively more efficient as compared to the Western and Central region in China. Results further found that the main contributor of economic inefficiency in China is mainly due to pure technical inefficiency. The technological change plays is found to play an important role in providing a road for sustainable economy development in China.
\end{abstract}

Index Terms-Productivity change, economy efficiency, inequality, Malmquist Index, China.

\section{INTRODUCTION}

The sustainability of the Chinese's economy attracts the attention of the world economist as China had successfully transformed itself from a closed-economy towards market-oriented economy system. This is witness with a spectacular economic growth of an average of nine percent per annum and further drive-up with China's accession to World Trade Organization (WTO). The key success factors of the Chinese's economic growth lies on the progressive opening in terms of trade and foreign investment after the China reformation in year 1978.

Nevertheless the success story of China is questionable with an increase in the inequality patterns among the provinces in China which could be harmful for the Chinese's economy development and performance overtime. The inequality among provinces is mainly due to underutilization and inefficient used of resources among the provinces in China [1]. This is witness with the differences in the development process experienced by the Eastern, Central and Western regions in the Chinese's economy.

The Eastern region developed tremendously over the years with an added advantage to adjust industrial structure with the formation of special economic zones and open cities. In addition the increase in the share of rural industry in this region had resulted in inefficient allocation of resources in the underdeveloped regions in the Western and Central

Manuscript received May 28, 2012; revised July 5, 2012.

S. G. Chan is a senior lecturer in Institute of China Studies, University of Malaya, 50603 Kuala Lumpur, Malaysia. (e-mail: sokgee@um.edu.my) regions. This segmented development process and inequality are harmful to the country's performance over time.

Consequently, this study aims to measure the economic efficiency and productivity of the provinces in China in conjunction with the inequality of the economic development among in this country. The non-parametric approach, namely, Total Factor Productivity (TFP) will be employs to investigate the source of inefficiency among the provinces in China with the goal to address the issues of inequality in the Chinese's provinces in terms of efficient used of resources in each province. The sample of the study consist of 30 provinces in China starts from year 1978 to 2008 in order to investigate the economic efficiency of the Chinese's economy after the China reformation in 1978.

The study is believed to improve the understanding of both academics and policy-makers on the root causes and patterns of the economy growth in each region. This is crucial in order for the authority to design policies for more equitable distribution on the regional basis. Besides, it also contributes to better policies formulation to allocate and redistribute the productive resources among the regions in reducing the issues of regional inequality in China.

\section{ECONOMIC CONDITIONS IN CHINA}

The Chinese's economy has impressively growth at a rate of more than 10 percent per annum from year 2003 to 2007. Besides, China overtook Japan as the world's second biggest economy after the USA at the second quarter of 2010 with a reported real GDP of RMB4,105.84 billion which is more than USD $\$ 1,337$ billion as compared to Japan.

\begin{tabular}{|c|c|c|c|c|c|c|c|}
\hline $\begin{array}{l}\text { Macroeconomics } \\
\text { Variables }\end{array}$ & 2002 & 2003 & 2004 & 2005 & 2006 & 2007 & 2008 \\
\hline $\begin{array}{l}\text { Real GDP growth } \\
(\%)\end{array}$ & 9.10 & 10.00 & 10.10 & 11.30 & 12.70 & 14.20 & 9.60 \\
\hline Gini coefficient (\%) & 43.40 & 45.80 & 47.90 & 49.20 & 50.00 & 50.40 & 50.80 \\
\hline Political stability & -0.18 & -0.32 & -0.14 & -0.25 & -0.31 & -0.28 & -0.32 \\
\hline Regulatory quality & -0.52 & -0.39 & -0.29 & -0.26 & -0.33 & -0.24 & -0.22 \\
\hline $\begin{array}{l}\text { Control for } \\
\text { corruption }\end{array}$ & -0.41 & -0.37 & -0.58 & -0.67 & -0.53 & -0.61 & -0.44 \\
\hline
\end{tabular}

Notes: all governance scores lie between -2.5 and 2.5 with higher scores represent better outcomes.

Source: Euromonitor International Database; Kaufmann et al. (2009)

Governance Matter VII

A tremendous increase of the rate of growth in China marks the effectiveness of the policies implemented and this can be seen with an improvement of governance effectiveness index starts from year 2006. Nevertheless, the 
growth in real gross domestic product (GDP) declined by 9.60 percent in year 2008 due to the global financial crisis which begins at the end of 2007.

Nevertheless, such growth remains as an issue with an increased in the Gini coefficient from 43.40 percent to 50.80 percent from 2002 to 2008. As highlighted by Euromonitor International 2011 report, China is predicted to have the highest level of income inequality in 2020 amongst the emerging market economies. The inequalities patterns creates a harmful scenario to the Chinese' economy because it might resulted in social economic issues. This situation is furthered dampening with a relatively weak governance index (Table I). Both political stability and regulatory quality indexes show a negative coefficient indicates that the country is still below average with in terms of political stability and regulatory control. Moreover, the country is still weak in terms of control for corruption as it reported a negative coefficient for this index since year 2002 to 2008. Consequently, increase of inequality among provinces might serve as a threat to the country economy performance. Therefore, the study of economic efficiency is crucial in order to understand the allocation of resources for each province that might result in inequality patterns.

\section{METhodology AND DATA}

\section{A. Methodology}

This study uses the Malmquist Total Factor Productivity (TFP) index to measure the economic efficiency and productivity of each province in China. The Malmquist TFP index is a panel data approach which allows for decomposition of the total factor productivity into overall technical efficiency, pure technical efficiency, scale efficiency, technical efficiency change, technological change, pure technical efficiency change, scale efficiency change and TFP change. This enables the identification of the root causes of inefficiency level for each province in this study.

The Malmquist TFP index is calculated based on the TFP change between two data points using the ratio of the distances of each data point relative to a common technology. The Malmquist TFP index for period $\mathrm{t}$ is given by Equation (1).

$$
m_{0}^{t}\left(y_{s}, x_{s}, y_{t}, x_{t}\right)=\left[\frac{d_{0}^{s}\left(y_{t}, x_{t}\right)}{d_{0}^{s}\left(y_{s}, x_{s}\right)} \times \frac{d_{0}^{t}\left(y_{t}, x_{t}\right)}{d_{0}^{t}\left(y_{s}, x_{s}\right)}\right]^{1 / 2}
$$

where $d_{0}^{s}\left(y_{t}, x_{t}\right)$ measures the distance from period $\mathrm{t}$ observation to the period s technology. If is greater than one, this indicates a positive growth in TFP from period $s$ to period $t$ whereas the TFP will be in a declining stage when is less than one.

Equation (1) can be rearranged as follows:

$$
m_{0}^{t}\left(y_{s}, x_{s}, y_{t}, x_{t}\right)=\frac{d_{0}^{t}\left(y_{t}, x_{t}\right)}{d_{0}^{s}\left(y_{s}, x_{s}\right)}\left[\frac{d_{0}^{s}\left(y_{t}, x_{t}\right)}{d_{0}^{t}\left(y_{t}, x_{t}\right)} \times \frac{d_{0}^{s}\left(y_{s}, x_{s}\right)}{d_{0}^{t}\left(y_{s}, x_{s}\right)}\right]^{1 / 2}
$$

This allows for further decomposition the TFP into efficiency change and technical change given by Equation (3) and (4) respectively.

$$
\begin{gathered}
\text { Efficiency change }=\frac{d_{0}^{t}\left(y_{t}, x_{t}\right)}{d_{0}^{s}\left(y_{s}, x_{s}\right)} \\
\text { Technical change }=\left[\frac{d_{0}^{s}\left(y_{t}, x_{t}\right)}{d_{0}^{t}\left(y_{t}, x_{t}\right)} \times \frac{d_{0}^{s}\left(y_{s}, x_{s}\right)}{d_{0}^{t}\left(y_{s}, x_{s}\right)}\right]^{1 / 2}
\end{gathered}
$$

According to [2] the technical efficiency change can be furthered decomposed into scale efficiency change and pure technical efficiency change if the distance functions are estimated relative to a constant return to scale (CRS) technology. Equation (5) and (6) are use to estimate scale efficiency change and pure efficiency change respectively.

$$
\begin{aligned}
& \text { Scale efficiency change }= \\
& {\left[\frac{d_{o v}^{t}\left(y_{t}, x_{t}\right) / d_{o c}^{t}\left(y_{t}, x_{t}\right)}{d_{o v}^{t}\left(y_{s}, x_{s}\right) / d_{o c}^{t}\left(y_{s}, x_{s}\right)} \times \frac{d_{o v}^{s}\left(y_{t}, x_{t}\right) / d_{o c}^{s}\left(y_{t}, x_{t}\right)}{d_{o v}^{s}\left(y_{s}, x_{s}\right) / d_{o c}^{s}\left(y_{s}, x_{s}\right)}\right]^{1 / 2}}
\end{aligned}
$$

$$
\text { Pure technical efficiency change }=\frac{d_{o v}^{t}\left(y_{t}, x_{t}\right)}{d_{o v}^{s}\left(y_{s}, x_{s}\right)}
$$

\section{B. Data and Definition of Variables}

This study uses a sample of 30 provinces starts from 1978 to 2008. The total number of observations is amounted to 930. The balanced-panel data is utilized in estimating the efficiency scores for each province from year 1978 to 2008 . We employ two inputs and one output in the estimation of Malmquist TFP index. The inputs use is total number of employed persons and capital stock calculated using Equation (7). This is then deflated using the GRP deflator $(1995=100)$.

$$
K_{t}=(1-\delta) K_{t-1}+I_{t}
$$

where $\mathrm{K}$ is the capital stock, $\mathrm{I}$ is the investment is the gross capital formation, is the depreciation rates and $t$ is used to represent the time period. According to [3], the depreciation rate of 4 percent should be used in the calculation of capital stock. The output used is real gross regional product (GRP) $(1995=100)$ and all the inputs and output vectors are value at RMB million. All data are extracted from various issues of provincial statistical yearbooks.

The descriptive statistics for the inputs and output use in this study are presented in Table II. This is calculated using the annual data from each provinces from year 1978 to 2008 .

The Eastern region reported the highest growth in terms of real gross regional product (GRP) with the reported figure of RMB242,740.62 million. This is followed by the Central and Western regions with the reported average of RMB129,827.34 million and RMB71,327.49 million respectively. This shows that on average the Eastern coastal growth is at least $85 \%$ more than the growth as compared to the growth rate in both the Central and Western region.

In addition, Table 2 also highlighted that the real capital 
stock in the Eastern region is amounted to RMB215,945.09 over the 30 years period and this again exceed the capital stock in both Central and Western region. Nevertheless, the total employment in the Central region is greater as compared to the Eastern and Western region with a reported total person employed of 22,35379000. Besides, even though the descriptive statistics show that the Eastern region is growing better than the Central and Western region, but the differences in terms of employment is less than $20 \%$ among all the regions. This might indicates the inefficient use of resources in the other regions.

TABLE II: DESCRIPTIVE STATISTICS FOR INPUTS AND OUTPUT VECTOR

\begin{tabular}{|c|c|c|c|}
\hline \multicolumn{4}{|c|}{$\begin{array}{r}\text { Eastern } \\
\end{array}$} \\
\hline $\begin{array}{l}\text { Descriptive } \\
\text { Statistics }\end{array}$ & $\begin{array}{c}\text { Real Gross } \\
\text { Regional } \\
\text { Product } \\
\\
\text { (RMB million) } \\
\end{array}$ & $\begin{array}{c}\text { Real Capital } \\
\text { Stock } \\
\text { (RMB } \\
\text { million) } \\
\end{array}$ & Employment \\
\hline $\begin{array}{l}\text { Mean } \\
\text { Standard }\end{array}$ & $242,740.62$ & $215,945.09$ & $18,979.12$ \\
\hline Deviation & $199,934.72$ & $272,078.56$ & $15,340.92$ \\
\hline Range & $1,282,646.77$ & $1,574,074.65$ & $59,661.00$ \\
\hline Minimum & $11,698.87$ & $3,290.71$ & $2,215.00$ \\
\hline Maximum & $1,294,345.64$ & $1,577,365.36$ & $61,876.00$ \\
\hline Count & 341 & 341 & 341 \\
\hline \multicolumn{4}{|c|}{ Central } \\
\hline $\begin{array}{l}\text { Mean } \\
\text { Standard }\end{array}$ & $129,827.34$ & $117,823.05$ & $22,353.79$ \\
\hline Deviation & $78,135.60$ & $135,642.94$ & $11,669.92$ \\
\hline Range & $412,306.17$ & $1,134,531.29$ & $51,896.00$ \\
\hline Minimum & $28,998.18$ & $8,127.92$ & $6,454.00$ \\
\hline Maximum & $441,304.36$ & $1,142,659.21$ & $58,350.00$ \\
\hline Count & 310 & 310 & 310 \\
\hline \multicolumn{4}{|c|}{ Western } \\
\hline $\begin{array}{l}\text { Mean } \\
\text { Standard }\end{array}$ & $71,327.49$ & $79,690.92$ & $14,975.78$ \\
\hline Deviation & $63,406.86$ & $91,652.45$ & $11,829.71$ \\
\hline Range & $332,888.75$ & $690,424.15$ & $46,044.00$ \\
\hline Minimum & $4,749.27$ & $8,853.53$ & $1,356.00$ \\
\hline Maximum & $337,638.01$ & $699,277.69$ & $47,400.00$ \\
\hline Count & 279 & 279 & 279 \\
\hline
\end{tabular}

\section{RESUlt AND DisCUSSION}

The results based on Malmquist TFP index estimates are presented in Table III, Table IV and Table V respectively. Table III shows the summary statistics of the average efficiency scores of all the provinces in the Eastern, Central and Western regions in in China from 1978 to 2008.

On average the Eastern region are relatively more efficient in using their inputs to achieve their economic growth as compared to the Central and Western region with an average efficiency score of 72.37 percent. This suggests that the region could have further increased their output or real GRP level by 27.63 percent given the same level of capital stock and employment. The result is consistent with the studies by [4]-[6].

TABLE III: AVERAGE EFFICIENCY SCORES OF PROVINCES IN CHINA

\begin{tabular}{|c|c|c|c|}
\hline Eastern & $\begin{array}{l}\text { Overall } \\
\text { technical } \\
\text { efficiency }\end{array}$ & $\begin{array}{l}\text { Pure } \\
\text { technical } \\
\text { efficiency }\end{array}$ & $\begin{array}{l}\text { Scale } \\
\text { efficiency }\end{array}$ \\
\hline Beijing & 0.774 & 0.821 & 0.942 \\
\hline Fujian & 0.645 & 0.661 & 0.977 \\
\hline Guangdong & 0.822 & 0.973 & 0.837 \\
\hline Hainan & 0.624 & 0.996 & 0.626 \\
\hline Hebei & 0.983 & 0.995 & 0.987 \\
\hline Jiangsu & 0.588 & 0.837 & 0.693 \\
\hline Liaoning & 0.650 & 0.653 & 0.992 \\
\hline Shandong & 0.534 & 0.797 & 0.664 \\
\hline Shanghai & 0.864 & 0.878 & 0.982 \\
\hline Tianjin & 0.603 & 0.708 & 0.859 \\
\hline Zhejiang & 0.875 & 0.897 & 0.959 \\
\hline $\begin{array}{l}\text { Average Efficiency } \\
\text { Scores }\end{array}$ & 0.724 & 0.838 & 0.865 \\
\hline \multicolumn{4}{|l|}{ Central } \\
\hline Anhui & 0.440 & 0.461 & 0.956 \\
\hline Guangxi Zhuang & 0.419 & 0.423 & 0.990 \\
\hline Heilongjiang & 0.546 & 0.556 & 0.980 \\
\hline Henan & 0.425 & 0.546 & 0.781 \\
\hline Hubei & 1.000 & 1.000 & 1.000 \\
\hline $\begin{array}{l}\text { Hunan } \\
\text { Inner Mongolia }\end{array}$ & 0.429 & 0.466 & 0.924 \\
\hline Autonomous & 0.422 & 0.457 & 0.922 \\
\hline Jiangxi & 0.361 & 0.368 & 0.982 \\
\hline Jilin & 0.447 & 0.470 & 0.950 \\
\hline Shanxi & 0.398 & 0.412 & 0.966 \\
\hline $\begin{array}{l}\text { Average Efficiency } \\
\text { Scores }\end{array}$ & 0.489 & 0.516 & 0.945 \\
\hline \multicolumn{4}{|l|}{ Western } \\
\hline Chongqing & 0.355 & 0.367 & 0.966 \\
\hline Gansu & 0.282 & 0.299 & 0.943 \\
\hline Guizhou & 0.287 & 0.302 & 0.953 \\
\hline Ningxia Hui & 0.312 & 0.999 & 0.312 \\
\hline Qinghai & 0.280 & 0.818 & 0.352 \\
\hline Shaanxi & 0.352 & 0.361 & 0.974 \\
\hline Sichuan & 0.391 & 0.488 & 0.810 \\
\hline Xinjiang & 0.509 & 0.577 & 0.881 \\
\hline Yunnan & 0.380 & 0.386 & 0.984 \\
\hline $\begin{array}{l}\text { Average Efficiency } \\
\text { Scores }\end{array}$ & 0.350 & 0.511 & 0.797 \\
\hline
\end{tabular}

Results found that Hubei emerged as the most efficient province in China and this is followed by Hebei and ZheJiang in the Eastern region with an average overall efficiency score of 98.30 percent and 87.50 percent respectively. Results also indicate that most of the provinces located in the Western region has an average overall efficiency scores of less than 50 percent except Xinjiang. The Qinghai province appears to be the least efficient province with an average overall efficiency score of 28 percent. This indicates that the province could have further reduces their inputs vector by at least 72 percent in order to achieve the given level of gross regional product. 
Such inefficiency might due to geographical disadvantage in Qinghai as compared to other provinces in China.

Results further indicate that the root source of inefficiency in all the regions is mostly due to pure technical inefficiency. This indicates that most of the regions in China are relatively weak in managing their inputs level in order to achieve the economic growth for each province. It is shown that most of the regions are operated in the right scale of operations with the reported average scale efficiency score of 86.53 percent, 94.51 percent and 79.72 percent for all the three regions respectively.

Table IV and V further decomposed the Malmquist TFP index estimation into technical change, technological change, pure technical efficiency change, scale efficiency change and TFP change in general.

TABLE IV: DECOMPOSITION OF MALMQUIST TFP INDEX OF THE REGIONS IN

\begin{tabular}{|c|c|c|c|}
\hline Eastern & $\begin{array}{l}\text { Technical } \\
\text { change }\end{array}$ & $\begin{array}{l}\text { Pure } \\
\text { technical } \\
\text { efficiency } \\
\text { change }\end{array}$ & $\begin{array}{l}\text { Scale } \\
\text { efficiency } \\
\text { change }\end{array}$ \\
\hline Beijing & 0.984 & 0.989 & 0.996 \\
\hline Fujian & 0.937 & 0.936 & 0.968 \\
\hline Guangdong & 0.938 & 0.954 & 0.953 \\
\hline Hainan & 0.946 & 0.968 & 0.946 \\
\hline Hebei & 0.957 & 0.962 & 0.962 \\
\hline Jiangsu & 0.939 & 0.948 & 0.959 \\
\hline Liaoning & 1.021 & 1.021 & 0.968 \\
\hline Shandong & 0.945 & 0.956 & 0.958 \\
\hline Shanghai & 0.949 & 0.954 & 0.963 \\
\hline Tianjin & 0.962 & 0.971 & 0.959 \\
\hline Zhejiang & 0.935 & 0.938 & 0.963 \\
\hline $\begin{array}{l}\text { Average } \\
\text { Efficiency Scores }\end{array}$ & 0.956 & 0.963 & 0.963 \\
\hline \multicolumn{4}{|l|}{ Central } \\
\hline Anhui & 0.955 & 0.956 & 0.968 \\
\hline Guangxi Zhuang & 0.966 & 0.966 & 0.968 \\
\hline Heilongjiang & 0.958 & 0.960 & 0.967 \\
\hline Henan & 0.949 & 0.955 & 0.962 \\
\hline Hubei & 0.968 & 0.968 & 0.968 \\
\hline $\begin{array}{l}\text { Hunan } \\
\text { Inner Mongolia }\end{array}$ & 0.969 & 0.968 & 0.969 \\
\hline Autonomous & 0.944 & 0.947 & 0.964 \\
\hline Jiangxi & 0.962 & 0.963 & 0.967 \\
\hline Jilin & 0.945 & 0.948 & 0.965 \\
\hline Shanxi & 0.956 & 0.958 & 0.966 \\
\hline $\begin{array}{l}\text { Average } \\
\text { Efficiency Scores }\end{array}$ & 0.957 & 0.959 & 0.966 \\
\hline \multicolumn{4}{|l|}{ Western } \\
\hline Chongqing & 0.960 & 0.962 & 0.966 \\
\hline Gansu & 0.960 & 0.964 & 0.964 \\
\hline Guizhou & 0.978 & 0.980 & 0.965 \\
\hline Ningxia Hui & 0.962 & 0.968 & 0.962 \\
\hline Qinghai & 0.969 & 0.989 & 0.960 \\
\hline Shaanxi & 0.955 & 0.956 & 0.967 \\
\hline Sichuan & 0.961 & 0.955 & 0.974 \\
\hline Xinjiang & 0.959 & 0.963 & 0.964 \\
\hline Yunnan & 0.966 & 0.967 & 0.967 \\
\hline $\begin{array}{l}\text { Average } \\
\text { Efficiency Scores }\end{array}$ & 0.963 & 0.967 & 0.965 \\
\hline
\end{tabular}

Results show that 29 provinces in China are experiencing a reduction in the productivity due to technical efficiency. The results indicate that the reduction in productivity in technical efficiency is due to reduction in the productivity in terms of pure technical efficiency change and this support the results found in Table III where the main contributor to the inefficiency in China is due to pure technical efficiency. Hence, further improvement in resource allocation is necessary in order to increase the productivity growth in all the provinces in China. On the other hand, Liaoning located in the Eastern region exhibit increase in productivity with an average of 2.10 percent per annum.

TABLE V: MALMQUiST TFP INDEX CHANGE AND TECHNOLOGICAL CHANGE OF THE REGIONS IN CHINA

\begin{tabular}{|c|c|c|}
\hline Eastern & $\begin{array}{l}\text { Technological } \\
\text { change }\end{array}$ & TFP change \\
\hline Beijing & 1.014 & 0.994 \\
\hline Fujian & 0.979 & 0.947 \\
\hline Guangdong & 0.982 & 0.951 \\
\hline Hainan & 0.965 & 0.942 \\
\hline Hebei & 0.990 & 0.977 \\
\hline Jiangsu & 0.995 & 0.964 \\
\hline Liaoning & 0.989 & 1.042 \\
\hline Shandong & 0.975 & 0.951 \\
\hline Shanghai & 0.987 & 0.966 \\
\hline Tianjin & 0.988 & 0.980 \\
\hline Zhejiang & 0.964 & 0.931 \\
\hline $\begin{array}{l}\text { Average Efficiency } \\
\text { Scores }\end{array}$ & 0.984 & 0.968 \\
\hline \multicolumn{3}{|l|}{ Central } \\
\hline Anhui & 0.955 & 0.943 \\
\hline Guangxi Zhuang & 0.960 & 0.959 \\
\hline Heilongjiang & 0.972 & 0.962 \\
\hline Henan & 0.963 & 0.945 \\
\hline Hubei & 0.933 & 0.933 \\
\hline $\begin{array}{l}\text { Hunan } \\
\text { Inner Mongolia }\end{array}$ & 0.958 & 0.959 \\
\hline Autonomous & 0.999 & 0.973 \\
\hline Jiangxi & 0.962 & 0.956 \\
\hline Jilin & 0.986 & 0.962 \\
\hline Shanxi & 0.973 & 0.961 \\
\hline $\begin{array}{l}\text { Average Efficiency } \\
\text { Scores }\end{array}$ & 0.966 & 0.955 \\
\hline \multicolumn{3}{|l|}{ Western } \\
\hline Chongqing & 0.963 & 0.956 \\
\hline Gansu & 0.961 & 0.952 \\
\hline Guizhou & 0.955 & 0.965 \\
\hline Ningxia Hui & 0.979 & 0.973 \\
\hline Qinghai & 0.976 & 0.976 \\
\hline Shaanxi & 0.965 & 0.951 \\
\hline Sichuan & 0.957 & 0.951 \\
\hline Xinjiang & 0.990 & 0.979 \\
\hline Yunnan & 0.962 & 0.961 \\
\hline $\begin{array}{l}\text { Average Efficiency } \\
\text { Scores }\end{array}$ & 0.968 & 0.962 \\
\hline
\end{tabular}

In general, the results show that all the provinces are experiencing a reduction in technical efficiency change, technological change, pure technical efficiency change, scale 
efficiency change and TFP change. From Table V, Beijing reported an average increased in technological change of 1.40 percent per annum. This indicates that technology advancement plays the role in promoting the growth of the productivity in Beijing.

Besides, technological change is found to contribute to the productivity growth in all the provinces with the reported average index change of 98.4, 96.6 and 96.8 for the Eastern, Central and Western region respectively. This might due to the adoption of advanced technology from the foreign investors as the government is encouraging the foreign direct investment into the country.

\section{CONCLUSION AND RECOMMENDATION}

This study addressed the issue of sustainability of the Chinese economy using the productivity analysis based on 30 provinces in China. The inequality in terms of efficiency and productivity is found among the regions in China with the Eastern region appears to be relatively more efficient as compared to the Central and Western regions. This is consistent with the regional studies in China, e.g. [4], [5] and [6]. This needs to be address by better policy implementation in order to avoid the effects of inequality towards the economic development in China.

The results also found that the main contributor to the economic inefficiency in most of the provinces came from pure technical inefficiency. Therefore, government may want to further evaluate their allocation of resources in order to create a more efficient use of capital stocks and labors in producing the output growth which contributes significantly towards a more sustainable economic growth in future.

The technological change plays is found to play an important role in providing a road for sustainable economy development in China. This shows that the adoption of advanced technology from the foreign investors due to increase of foreign direct investment is crucial for the country economy. This is consistent with the findings of previous studies, e.g. [7], [8], [3]. However, government should further encourage the innovation of new technologies in the production process as the adoption of technologies from the foreign countries does not lead to a promising long-term growth [3]. Hence, government policies should focus on giving more incentives and encouragement in the research and development industries especially dealing with invention and innovation.

\section{REFERENCES}

[1] G. Wan, M. Lu, and Z. Chen, Z, "The inequality-growth nexus in the short and long run: Empirical evidence from China," J. Compar. Econ., 2006, vol. 34, no. 4, pp. 654-667.

[2] R. Färe, S. Grosskopf, M. Norris, and Zhang, "Z. Productivity growth, technical progress and efficiency change in industrialized countries," Amer. Econ. Rev., no. 84, 1994, pp. 66-83.

[3] J. Zheng and A. Hu, "An empirical analysis of provincial productivity in China (1979-2001)," Journal of Chinese Econ. and Bus. Stud., vol. 4, no. 3, 2006, pp. 221-239.

[4] C. Yu, "Evidence of the effect of openness policy on TFP and its components: The case of Chinese provinces," Working Papers in CERDI, 2009, Université d' Auvergene.

[5] A. Heshmati and S.C. Kumbhakar, "Technical change and total factor productivity growth: The case of Chinese provinces," Technology Forecasting \& Social Change, no. 78, 2011, pp. 575-590.

[6] K.W. Li and T. Liu, "Economic and productivity growth decomposition: An application to post-reform China," Econ. Modelling, no. 28, 2011, pp. 366-373.

[7] A. Maddison, "The Chinese Economy: A Historical Perspective," 1998, OECD, Paris.

[8] J. Zheng, X. Liu, and A. Bigsten, "A. Efficiency, technical progress, and best practice in Chinese state enterprises (1980-1994)," J. Compar. Econ., no. 31, 2003, pp. 134-152.

[9] D. Kaufmann, A. Kraay, and M. Mastruzzi, "Governance matters VIII. Policy Research Working Paper 4978. The World Bank," Macroeconomics and Growth Team, 2009, 1-105.

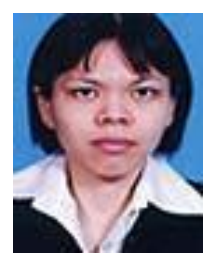

S. G. Chan was born in Malaysia, 1979. Chan completed her Ph.D in Economics in The Northern University of Malaysia with the specialization in bank efficiency analysis. She is currently working in one of the leading university in Malaysia, namely, University of Malaya, Malaysia as a senior lecturer. Chan research interest is in bank efficiency analysis and economic efficiency analysis in the ASEAN region. 